Student Success

ISSN: 2205-0795

Volume 8, Issue 2, pp. 123-129

J uly 2017

\title{
Do you hear me? Student voice, academic success and retention
}

\author{
Jennifer Allen and Catherine Nichols
}

University of Newcastle, Newcastle, Australia

\begin{abstract}
*
The place of student voice, whilst present in the evaluation of the teaching and learning process in higher education institutions, is limited in the planning, provision and ownership of student support services that promote student success and retention. This project seeks to recognise that students have an active role and partnership in constructing their own success and their voice is integral to this partnership. To promote the importance of the student voice at the University of Newcastle (UON), this initiative has established the Office of Student Advocacy (OSA). This is a collaborative enterprise between university staff and student associations, a communication strategy for student-elected representatives on university committees and, a reporting mechanism for student concerns to be communicated to the relevant decision makers at UON. The project repositions students as co-creators of student support to inform student success.
\end{abstract}

*This 'Emerging Initiative' was first presented at the 2017 STARS Conference in Adelaide, Australia in July 2017 and was selected by the Conference Committee as one of the top-rated reports. The authors have kindly given their permission to have this report published in this special issue of the Journal and it has undergone a further review by the editors to confirm it aligns with the Journal format.

Please cite this article as:

Allen, J. \& Nichols, C. (2017). Do you hear me? Student voice, academic success and retention. Student Success, 8(2), 123-129. doi: $10.5204 /$ ssj.v8i2.387

This practice report has been accepted for publication in Student Success. Please see the Editorial Policies under the 'About' section of the Journal website for further information.

Student Success: A journal exploring the experiences of students in tertiary education

(c) (i) This work is licensed under a Creative Commons Attribution 4.0 International Licence. As an open access journal, articles are free to use, with proper attribution, in educational and other non-commercial settings. ISSN: 2205-0795 


\section{Introduction}

An ongoing tension in student support services in higher education is the premise that students as adult learners engage with supports initiated by the institution, placing students as being responsible for their academic progression. However, Blair and Valdez Noel (2014) consider universities as partnering in this responsibility. They contend that the place of the student voice, whilst present in the evaluation of the teaching and learning process in the classroom, is limited in the planning, provision and ownership of student support services. Thus, a danger of student-centred approaches is that the institution assumes the needs of students within an authoritarian approach to student support. However, this project contends that student-centred approaches should define students as "partners" in the construction of their success and "co-conspirators" with an active role whereby university staff speak with, not for, students.

This emerging initiative privileges student voice in planning for student success and retention. The project acknowledges the legislative Higher Education standards and the Student Services, Amenities, Representation and Advocacy guidelines of the Australian Higher Education Support Act (2003) seeking innovative ways to encourage student advocacy. To achieve this, the UON has established: an Office of Student Advocacy; a collaborative enterprise between staff and student associations, a reporting mechanism to communicate student concerns to the relevant decision makers and, a communication strategy for student-elected representatives on university committees to develop a shared student voice. The goal is to reposition the students as co-creators of student support to invest in themselves and inform student success. Cornelius and Wood (2012) suggest that a supportive environment provides a forum for students to discuss issues that may impact on their retention. This project aims to provide such a forum.

\section{Advocacy, student partnership and student voice in Australian universities}

The increase in valuing student voice in higher education has, according to Blair and Valdez Noel (2014), forced universities to rethink their construction of knowledge as the ownership of power expands. The student voice is often heard in relation to evaluations of teaching and learning however limited in a broader university context. It appears that even if a university values the student voice, additional support is needed to engage them as change agents. This project values the concept of empowerment agents to focus on empowering students.

The student voice is supported in this project as saying something worth hearing, with rich insight as partners in their own success. In the UK context, the Quality Assurance Agency for Higher Education (QAA), Higher Education Academy (HEA) and Student Partnerships in Quality Scotland (SPARQS) highlight the importance of student partnership in privileging student voice as co-workers and cocreators of not only curriculum but also institutional practices. In the Australian context, Matthews (2016) promotes student partnership as an ethos not an activity and Varnham, Olliffe, Waite and Cahill (2015) note that students engaging with student representation strengthens their "knowledge, experience and expertise" in governance and decision making and leads to a stronger, more confident student voice (p. 12). This project however is not naïve of power relations in universities and the theoretical work of Habermas and Cooke (2000) and Foucault (1982) inform the project. Students will need to develop communicative competence in interactions with others that move beyond structural views of power. Power is thus not 
owned by the staff and students are not constructed as the "other" and marginalised. Rather, they are valued in everyday interactions in a contested space. Students are not informed and advised what is best for them, but educated in realising the potential present in their voices by developing the cultural and linguistic capital needed to engage in interactions with staff. Whilst research by Bromley and Powell (2012) demonstrated how student activism can change the practices of educational institutions to better meet the needs of students, Blair and Valdez Noel (2014) found little evidence to show that student evaluations actually lead to real change. This project seeks real change and greater student success and retention in an environment that Gibson et al. (2016) describe as entrenched in practices that do not empower or widely consult students.

\section{An Office of Student Advocacy (OSA)}

Universities as complex organisations have become more diverse with increasing numbers of older, international, disabled, indigenous and low SES students (Quinlan, Clarke, \& Miller, 2016). Students without the cultural and social capital to make sense of university processes will be disadvantaged; and as culturally distinct from the dominant university culture, report that no-one cares about their success noted as a reason to cease their studies (The RP Group, 2014). Contact with a significant person is also reported as a crucial factor in student retention and Plageman (2011) describes the importance of a mutually strong commitment between students and the university. This project endorses the provision of a student advocate and, whilst some institutions of higher education prescribe this as the responsibility of student associations, this initiative seeks to locate this as core business of the university. The OSA is independent of decision making at the UON to counter a conflict of interest but is located on the staff of UON.

The OSA was established to provide access for all students to professional advocacy services with independent representation within the UON community. The OSA's role is to advocate for students' interests in matters arising under the higher education provider's rules. The positions are in keeping with the Student Services, Amenities, Representation and Advocacy guidelines of the Higher Education Support Act (2003) that outlines the standards required to comply with the legislation. The OSA is a support service that will:

- provide coursework and higher research degree students with independent advice, support and advocacy on issues that negatively affect their academic performance;

- act in the best interests of the student at all times, in line with the University of Newcastle and government regulations;

- uphold the principles of natural justice and procedural fairness;

- support students if there has been a breach of UON policy or procedure;

- support students in putting their best case forward if appealing university decisions;

- provide educational resources for students in issue resolution/advocacy skills; and

- inform the UON of ongoing issues that require a University response to improve the academic experience of all students.

The focus of OSA not only is responsive to the needs of students in relation to issue resolution but also provides an educative role. Students are encouraged to engage in ownership of the issue resolution process as the OSA recognises 
the danger that providing advocacy may reproduce existing definitions of the student that discourage their agency and capacity to take responsibility. To contest this, the OSA seeks an educative, reciprocal and dialogic approach. Key assumptions of the office reflect the research of Robinson and Taylor (2007) and recognise that (a) communication is dialogue, (b) participation requires democratic inclusivity, (c) power relations are unequal; and (d) change and transformation is possible. The student advocates seek to move away from structural and governance reforms toward relational reform as described by Smyth (2006).

The role of the student advocates is also to focus on "sensemaking" (Bagdasarov et al., 2016 , p. 141) through policy advice and seeking out rationales from the university for students to not only understand the decisions made but also to promote the student voice when asked to "show cause" for retention. Thus, whilst the historical notion that academic advising is entirely prescriptive in naturemuch like a doctor-patient relationship-the OSA operates to encourage a decision making process where students realise their own potential through a collaborative dialogic process. The student advocate models skills and communicative competence. The place of language in the process of control is also recognised by the OSA and resource development and referral for language support has been a key function to promote linguistic capital.

The focus of the resources available through the OSA promotes stronger self-determination skills and self-management skills. Getzel's (2008) research recognises the importance of these skills in student success and retention. To promote student engagement in the issue resolution process and the educative role of the OSA, self-help materials continue to be developed to support key themes of issues that emerge for students. These materials provide advice in relation to UON rules, policies and procedures to not only assist understanding but also promote effective and professional engagement with the processes required by UON. Examples of the types of resources include information about UON support available to ensure academic success, advocacy and professional skills, summarising relevant policies, appeals of grade and show cause for academic progress, misconduct (academic and non-academic matters), developing professional academic communication and issue resolution.

\section{A collaborative enterprise between university staff and student associations: SEDOSA}

This UON project recognises that "student learning and development also occurs outside the classroom" (Herdlein \& Zurner, 2015, p. 1). To capture this, the OSA and the Office of the Dean of Students (ODOS) have undertaken a collaborative enterprise with the student associations across the campuses of UON. This enterprise is known as the Student Entities, Dean of Students and Office of Student Advocacy group (SEDOSA). This partnership provides OSA, ODOS and the student associations with a forum to discuss student needs and provides a collaborative student voice to examine themes that emerge for students that require advocacy support. The key assumption of this group is, as described by Chaubey and Krivacek (2016), that a "culture of trust is a precondition of success" (p. 7). The terms of reference of the group state that SEDOSA must act in the best interest of students at all times and ensure that the student voice is considered in the decision making of the university. Thus, the information discussed in this group is disseminated to key UON decision makers for action. 


\section{Reporting student concerns to decision makers at UON}

The student voice is only effective if it can be heard by the relevant decision makers within UON. This project has formalised the process for communicating student recommendations to the relevant stakeholders. The OSA, ODOS and SEDOSA prepare reports for the UON Teaching and Learning committee and Academic Senate. In these forums, recommendations are presented with the plan to evaluate resultant action regularly. There are also regular meetings between the members of SEDOSA and the Deputy Vice Chancellor (Academic) to ensure the student voice is heard and appropriate action recommended.

\section{A communication strategy for student-elected representatives: $A$ shared voice}

To further complement the role of the OSA, ODOS and SEDOSA, a regular meeting of all student representatives on UON committees is conducted to consider strategies to promote student success. The students are provided training in governance and future resources will seek to develop their communicative and professional competence. There has been concern that students speak on behalf of their own issues rather than representing the voice of their stakeholders. Gathering these students together has provided a communication strategy to develop a shared voice which then reports back through the various committees. The intent is to provide support for students otherwise isolated in their respective committees and portfolios.

\section{Impact of the Initiatives}

This initiative has shown effectiveness both through responsive and proactive strategies. The OSA in partnership with the ODOS has supported approximately 680 students in 2016 with an impact on success and retention. Interestingly, the OSA has provided support for students for internal transfer to more suitable degree programs where success and retention is more achievable. The OSA has also supported student responses to the "at risk" process reducing the numbers of automatic exclusions due to non-response. Student issues have been presented at Academic Senate and the Teaching \& Learning Committee and recommendations for change have emerged for action. SEDOSA has provided a forum for the discussion of recommended institutional improvements and a key unexpected benefit has been the establishment of communication and shared resources between the associations. The gathering of the student representatives on the UON committees requires further attention as an unexpected challenge has been the perceived role of some students as individual advancement and finding a shared voice is still a work in progress. Another challenge has been the dual worlds that staff and students operate in and the limited time for shared discussions. It has therefore been helpful that the more formal channels of communication promoted in this project are reporting success.

\section{Conclusion}

In discussing attrition, this project concludes that the burden of responsibility is not solely on the student but shared by the educational institution they attend. Student voice is integral to genuinely hear from the student population their recommendations for change as producers of their own success. Robinson and Taylor (2007) recount the hope of the "coming of age" of the student voice in higher education institutions and its initial optimism. However, they suggest this has not yet been realised but this emerging initiative has provided UON students with renewed hope. Whilst Smyth (2006) suggests that the absence of the student voice can lead to resistance, this project 
contends that its presence can lead to student success.

In respect to an overview of the outcomes of the presentation at the 2017 STARS Conference, it was noted that student voice is an ongoing interest area for the participants, particularly in relation to constructions of student voice as partners in decision making, and professional advocacy for students in the early intervention space requiring further deliberate attention. University staff noted the role of complaints, student ombudsmen, Deans of Students and student advocates and queried possible distinctions between these roles. Discussion emerged in issues of early intervention as distinct to final port of call processes, and the need for not only local level engagement in advocacy but also student input into decision making, with professional trained advocacy support. It was noted that the goal of increased student success and retention in Australian universities should be framed in discussion and innovative approaches that promote the student voice as coconspirators - co-conspirators with an active role in the decision making processes that impact on their success.

\section{References}

Bagdasarov, Z., Johnson, J., MacDougall, A. Steele, L., Connelly, S., \& Mumford, M. (2016). Mental Models and Ethical Decision Making. Journal of Business Ethics, 138(1), 133-144. Retrieved from https://us.sagepub.com/en-us/nam/journal-ofempirical-research-on-human-researchethics/journal202321

Blair, E., \& Valdez Noel, K. (2014). Improving higher education practice through student evaluation systems. Assessment \& Evaluation in Higher Education, 39(7), 879-894. http://dx.doi.org/10.1080/02602938.2013.875984

Bromley, P., \& Powell, W. (2012). From smoke and mirrors to walking the talk. Academy of Management Annals, $6(1)$, 483-530. https://doi.org/10.1080/19416520.2012.684462
Chaubey, M., \& Krivacek, G. (2016). Measures of Quality in Higher Education. Allied Academies International Conference. Academy of Educational Leadership. Proceedings. Academy for Economics and Economic Education. 21(1), 4-8.

Cornelius, V., \& Wood, N. (2012). Academic to student mentoring within a large business school. Asian Social Science, $8(14), \quad 1-8$. http://dx.doi.org/10.5539/ass.v8n14p1

Foucault, M. (1982). The subject and power. Critical inquiry, $8(4)$, https://doi.org/10.1086/448181

777-795.

Getzel, E. (2008). Addressing the persistence and retention of students with disabilities in higher education. Exceptionality, 16(4), 207-219. http://dx.doi.org/10.1080/09362830802412216

Gibson, S., Baskerville, D., Berry, A., Black, A., Norris, K., \& Symeonidou, S. (2016). 'Diversity', 'Widening Participation' and 'Inclusion' in Higher Education: An International study. Widening Participation and Lifelong Learning, 18(3), 7-33. https://doi.org/10.5456/WPLL.18.3.7

Habermas, J., \& Cooke, M. (2000). On the pragmatics of communication. MIT press.

Herdlein, R., \& Zurner, E. (2015). Student Satisfaction, Needs, and Learning Outcomes: A Case Study Approach at a European University. SAGE Open, 5(2). 1-10. doi: 10.1177/2158244015580373

Plageman, P. (2011). Educator, planner and advocate: Higher Education for Adults in the New Millennium. Adult Learning, 22(2), 32-36. https://doi.org/10.1177/104515951102200205

Matthews, K. (2016, July). Student Voice in Curriculum Review: Students as Partners. Paper presented at the Australian Council of Deans of Science Education Conference, Sydney University, Sydney, NSW.

Quinlan, E., Clarke, A., \& Miller, N. (2016). Enhancing Care \& Advocacy for Sexual Assault Survivors on Canadian Campuses. Canadian Journal of Higher Education, 46(2), $40 . \quad$ Retrieved from http://journals.sfu.ca/cjhe/index.php/cjhe/index

Varnham, S., Olliffe, B., Waite, K., \& Cahill, A. (2015). Starting a Conversation about Student Voice: Student Voice in University Decision Making. Student engagement in university decision-making and governance- towards a more inclusive student voice. Retrieved from the UTS Initiatives website https://www.uts.edu.au/sites/default/files/article/ downloads/Starting\%20a\%20conversation.pdf

Robinson, C., \& Taylor, C. (2007). Theorizing student voice: values and perspectives. Improving schools, 10(1), 517. doi: $10.1177 / 1365480207073702$

RP Group (2014). Practically speaking. Community college practices that help (re)define student support. 
Retrieved from

http://files.eric.ed.gov/fulltext/ED548259.pdf

Smyth, J. (2006). 'When students have power': student engagement, student voice, and the possibilities for school reform around 'dropping out' of school. International Journal of Leadership in education, 9(4), 285-298.

http://dx.doi.org/10.1080/13603120600894232 